J. Clin. Chem. Clin. Biochem.

Vol. 28, 1990, pp. $845-850$

(C) 1990 Walter de Gruyter \& Co. Berlin · New York

\title{
On the Possibility of Differential Diagnosis at Elevated Erythrocyte Sedimentation Rate by Analysis of the Concentrations of Blood Plasma Proteins - A Model Study ${ }^{1}$ )
}

\author{
By G. Ruhenstroth-Bauer ${ }^{1}, K$. Schedler $^{1}, R$. Scherer ${ }^{1}$ and $O$. Vesterberg ${ }^{2}$ \\ 1 Max-Planck-Institut für Biochemie, Martinsried, Germany \\ ${ }^{2}$ National Institute of Occupational Health, Division of Medical Chemistry, Solna, Sweden
}

(Received May 14, 1990)

Summary: An elevated erythrocyte sedimentation rate is generally regarded as an unspecific and mostly pathological indicator of inflammation or tumour. However, we have determined the concentrations of plasma/serum proteins that influence the erythrocyte sedimentation rate in numerous samples from several groups of patients with different diseases, including 2 forms of cancer. Equations have been developed by which the $1 \mathrm{~h}$ value of erythrocyte sedimentation rate can be expressed as the sum of disease-specific coefficients for each protein multiplied by the measured concentrations of the respective proteins. These equations are shown to be disease-specific with $64-93 \%$ probability. Such equations may thus form the basis for differential diagnosis.

\section{Introduction}

Since the fundamental work of Fåhraeus (1) and Westergren (2), an elevated erythrocyte sedimentation rate has been looked upon as an unspecific and mostly pathological indicator, which is often elevated on both acute and chronic inflammation states, various types of cancer and during the last months of pregnancy. Even in the mentioned studies, it was recognized that an elevated erythrocyte sedimentation rate is usually accompanied by an increased fibrinogen concentration. We showed in 1966 (3) that elevated concentrations of several plasma proteins, such as coeruloplasmin, haptoglobin or $\alpha_{1}$-macroglobulin, can also cause an elevated erythrocyte sedimentation rate. We named these proteins agglomerins (4).

Evidence for some disease-related specificity of the erythrocyte sedimentation rate was first mentioned in

\footnotetext{
1) This research was supported in part by Texmana AG, CH-6052 Hergiswil, Switzerland.
}

1975 (5). We observed that irrespective of age, sex or duration of diseases in different groups of diseases with elevated erythrocyte sedimentation rate, the values of the correlation coefficients for the concentration of different agglomerins had a disease specific order. This observation is supported by the finding that the ratios between the concentrations of the investigated plasma proteins remain fairly constant during the course of a heart infarct or other diseases (5). Also, the observation that an elevated erythrocyte sedimentation rate is decreased to different extents by prednisolone, depending on the accompanying disease, favours the assumption that the erythrocyte sedimentation rate mechanism is specific (6). This prompted the following model study on patient groups with different diseases, aimed at the development of a procedure for differential diagnosis, based on analysis of the relationship between elevated erythrocyte sedimentation rate and the concentrations of certain plasma proteins. 


\section{Materials and Methods}

The study consists of three parts with respectively four (part I) and two (part II and III) groups of patients, each group consisting of patients with an identical disease. No selection for the patient age and the stage of their diseases was made.

Serum and citrated blood $(1+4)$ were obtained from the patients and $5 \mathrm{ml}$ of the blood was centrifuged $(10 \mathrm{~min}, 3000 \mathrm{~g})$. To normalize the concentrations of erythrocytes, a mixture of $1 \mathrm{ml}$ of the supernatant plasma and $0.5 \mathrm{ml}$ packed erythrocytes was used. The further procedure for determining the $1 \mathrm{~h}$ erythrocyte sedimentation rate was performed according to the rules for standardization of the erythrocyte sedimentation rate (7). The correlation coefficient $r$ of duplicate measurements of the $1 \mathrm{~h}$ value was 0.96 . Serum and plasma samples were stored at $-70^{\circ} \mathrm{C}$ before analysis.

In the plasma the concentration of fibrinogen was determined by immunodiffusion (NOR-Partigen plates Behring-Werke D$3550 \mathrm{Marburg} / \mathrm{Lahn}$, Germany). In sera, the concentrations of the following serum proteins were measured by immunodiffusion (Partigenplates; Behringwerke, D-3550 Marburg/Lahn, Germany): C-reactive protein, immunoglobulin A, immunoglobulin $G$ and immunoglobulin $M$. In parts I and III of the study the following serum proteins were further assayed by the method of Clarke-Freeman (8): albumin, acid- $\alpha_{1}$-glycoprotein, $\alpha_{1}$-antitrypsin, $\alpha_{1}$-lipoprotein, $\alpha_{2}$-macroglobulin, complement $\mathrm{C}_{3}$, coeruloplasmin, haptoglobin, prealbumin, transferrin.

The mean imprecision of the protein concentration values measured by the Clarke-Freeman method was $\mathrm{CV}< \pm 5.5 \%$. In part II zone immunoelectrophoresis assay (ZIA) (9) was used instead of the method of Clarke-Freeman for measurement of the respective protein concentrations. The imprecision of zone immunoelectrophoresis assay is $\mathrm{CV} \pm 3 \%$ (10).

By measuring the erythrocyte sedimentation rate and the plasma/serum protein concentrations of every patient, we obtained one block of values for each group of patients.

\section{Patients}

Patients came from the University clinics of Munich and Lübeck (Germany) with clinically asserted diagnoses.

\section{Part I}

Four groups of patients were investigated with the following diseases: erysipela, malignant melanoma, multiple sclerosis and carcinoma of the uterus. These 4 groups were chosen as examples of an acute inflammation, a very acute tumour, a chronic inflammation and a tumour with a more protracted course. All erysipela patients had been hospitalized due to the severity of their disease. Table 1 shows the mean age and the sex distribution as well as the mean duration time of acute multiple sclerosis patients and of the other groups when the blood was taken. The melanoma patients were hospitalized because of known or suspected metastases. The time since operation of the primary tumour is indicated in table 1 . The diagnosis of patients with multiple sclerosis was ensured by the typical multiple sclerosis liquor inflammation state and computer NMR tomography (11). The blood of the patients with uterus carcinoma had been taken before the operation of the tumour

\section{Part II}

In this part the values of two other groups of multiple sclerosis and uterine carcinoma patients different from those in part I were investigated.

\section{Part III}

In this part, the values of the patients of part I with multiple sclerosis were compared with those of another group with different kinds of inflammation of the central or peripheral neurological system, such as encephalitis, herpes zoster or neuritis.

Tab. 1. Clinical data of the patient groups (n.d. = not determined)

\begin{tabular}{|c|c|c|c|c|c|c|}
\hline $\begin{array}{l}\text { Part of } \\
\text { study }\end{array}$ & Disease & $\mathrm{n}$ & $\delta / 9$ & $\begin{array}{l}\text { Mean age } \\
\text { (years) }\end{array}$ & $\begin{array}{l}1 \mathrm{~h} \text {-mean ESR } \\
\text { values }(\mathrm{mm})\end{array}$ & $\begin{array}{l}\text { Mean duration } \\
\text { of disease }\end{array}$ \\
\hline \multirow[t]{4}{*}{1} & Erysipela & 40 & $11 / 29$ & $42.2 \pm 10.4$ & $88.93 \pm 26.62$ & $4.0 \pm 3.5$ days \\
\hline & $\begin{array}{l}\text { Malignant } \\
\text { melanoma }\end{array}$ & 13 & $8 / 5$ & $40.5 \pm 15.3$ & $75.85 \pm 44.90$ & $1.4 \pm 2.5$ years \\
\hline & $\begin{array}{l}\text { Multiple } \\
\text { sclerosis }\end{array}$ & 15 & $7 / 8$ & $35.2 \pm 15.0$ & $33.03 \pm 25.33$ & $5.2 \pm 3.5$ years \\
\hline & $\begin{array}{l}\text { Uterine } \\
\text { carcinoma }\end{array}$ & 22 & $0 / 22$ & $58.2 \pm 10.0$ & $61.88 \pm 23.18$ & n. d. \\
\hline \multirow[t]{2}{*}{2} & $\begin{array}{l}\text { Multiple } \\
\text { sclerosis }\end{array}$ & 19 & $13 / 6$ & $40.1 \pm 12.9$ & $37.13 \pm 26.72$ & n.d. \\
\hline & $\begin{array}{l}\text { Uterine } \\
\text { carcinoma }\end{array}$ & 19 & $0 / 19$ & $56.1 \pm 12.3$ & $56.66 \pm 19.57$ & n. d. \\
\hline \multirow[t]{2}{*}{3} & $\begin{array}{l}\text { Multiple } \\
\text { sclerosis }\end{array}$ & 15 & $7 / 8$ & $35.2 \pm 15.0$ & $33.03 \pm 25.33$ & $5.2 \pm 3.5$ years \\
\hline & $\begin{array}{l}\text { Inflammatory } \\
\text { diseases of the } \\
\text { nervous system }\end{array}$ & 15 & $9 / 6$ & $30.1 \pm 9.5$ & $52.16 \pm 27.04$ & n.d. \\
\hline
\end{tabular}

$\mathrm{ESR}=$ erythrocyte sedimentation rate 


\section{Calculation (12)}

At the beginning of the study we calculated a simple linear regression function between erythrocyte sedimentation rate and the concentration for each single protein, using all the individual values from every group. After that, the difference between the calibration (regression line) value and the measured value was determined for each plasma protein concentration of every patient. The disease with the greatest number of minimal differences was taken as the diagnosis. However, by this procedure the number of errors was considerably greater compared with the multiple regression method described below.

By the method of stepwise linear regression a certain $T$-value of significance was stated. Then in each group the regression equation with all parameters (plasma/serum concentration against erythrocyte sedimentation rate) was calculated, and all parameters transgressing the chosen $\mathrm{T}$-value was eliminated stepwise.

The basis of these calculations was each block of values from patients with the different diseases. The plasma/serum protein concentration of each patient was expressed in percent of the assigned normal values of human serum (Behring-Werke, D$3550 \mathrm{Marburg} / \mathrm{Lahn}$, Germany). In the first part of the study the plasma/serum values were normalized so that the values equalling the assigned normal values became zero. Higher values are given in percent of the assigned values. In the two other parts of the study, the normal values were assigned a value of 100.

For each group this procedure led to a vector of coefficients for every parameter of the equation. The coefficients of the equations were obtained by using the sum of squares of deviations to obtain a minimum when using all measured concentrations of plasma/serum proteins of all patients of one block.

We then compared again in every part of the study the calculated erythrocyte sedimentation rate of each patient with the measured erythrocyte sedimentation rate. The value closest to one of the values of an equation was taken for the probable diagnosis.

For these calculations we developed a program in Pascal. To test the quality of the regression we used three values: the Ttest (the significance of impact of a certain coefficient of an equation) the F-test (the probability of the independence of erythrocyte sedimentation rate (ESR) on certain parameters of the model) and the $\mathrm{R}^{2}$-value (the multiple correlation coefficient):

$$
\mathrm{R}^{2}=1-\frac{\Sigma\left(\mathrm{ESR}_{\mathrm{i}}-\widehat{\mathrm{ESR}}\right)^{2}}{\Sigma\left(\mathrm{ESR}_{\mathrm{i}}-\widehat{\mathrm{ESR}}\right)^{2}}
$$

$\mathrm{ESR}_{\mathrm{i}}=$ measured ESR of a patient

$\widehat{\mathrm{ESR}}=$ "Calculated" $\mathrm{ESR}$

$\overline{\mathrm{ESR}}=$ mean value of ESR of a group.

In this way equations of the following type were obtained: 1-hour value of

$\widehat{\mathrm{ESR}}=$

$\mathrm{c}_{1} \times \mathrm{Alb}+\mathrm{c}_{2} \times \mathrm{A} 1 \mathrm{a}+\mathrm{c}_{3} \times \mathrm{Coe}+\ldots+\mathrm{c}_{15} \times$ Tra.

$c_{1}$ to $c_{15}$ are fixed coefficients, and the three letters represent the concentrations of the plasma/serum proteins albumin, $\alpha_{1}$ antitrypsin, coeruloplasmin, transferrin in percentage of the normal values.

We applied every equation to the concentrations of all the plasma/serum proteins which had been estimated in each individual in each block. Moreover, within the blocks those proteins were excluded which had no or almost no influence on the variability of the erythrocyte sedimentation rate values expressed by $\mathrm{R}^{2}$.

\section{Results}

In part I, 40 patients with erysipela, 13 with malignant melanoma, 15 with multiple sclerosis and 22 with uterine carcinoma were studied. Table 2 shows the resulting equations. In part II we measured the erythrocyte sedimentation rate values and the plasma/serum protein profiles of 19 patients with multiple sclerosis and 19 with uterine carcinoma. In table 4 the resulting equation is given. In part III the values of the 15 patients with multiple sclerosis of part 1 , and of 15 patients with no multiple sclerosis inflammation of the nervous system formed the basis for the two equations (tab. 6). The equations also gave some negative correlations, especially with albumin.

Table 2 demonstrates that in the four equations of part I the corresponding coefficients for specific plasma/serum protein concentrations showed distinct differences, for example for fibrinogen $0.86,0.26,2.40$ and 2.05. Therefore, we supposed that the concentration values taken as a whole of any patient of the four blocks would best fit the equation of their own block,

Tab. 2. Equations for four diseases using the plasma concentrations of 10 or 9 plasma proteins in part I of the study. ESR = Erythrocyte sedimentation rate

\section{Proteins:}

acid $\alpha_{1}$-glycoprotein

albumin

$\alpha_{1}$-antitrypsin

coeruloplasmin

complement $\mathrm{C} 3$

$\mathrm{C}$-reactive protein

haptoglobin

immunoglobulin $\mathrm{A}$

immunoglobulin $\mathrm{G}$

immunoglobulin $\mathrm{M}$

$\alpha_{1}$-lipoprotein

$\alpha_{2}$-macroglobulin

prealbumin

transferrin

Alb

A1a

Coe

$\mathrm{CC} 3$

Crp

Hap

IgA

IgG

IgM

A11

A2m

Pre

Tra
Equation for malignant melanoma

$\mathrm{ESR}=1.76 \times \mathrm{Alb}-0.89 \times \mathrm{A} 1 \mathrm{~g}+1.32 \times \mathrm{A} 1 \mathrm{a}-0.95$ $\times \mathrm{Coe}+1.16 \times \mathrm{Crp}+0.26 \times \mathrm{Fib}+0.45 \times \mathrm{Hap}$ $+1.54 \times \operatorname{IgA}-1.56 \times$ Pre $-1.95 \times \operatorname{Tra}+240$

Equation for multiple sclerosis

$\mathrm{ESR}=-11.7 \times \mathrm{Alb}-0.07 \times \mathrm{A} 1 \mathrm{~g}+1.82 \times \mathrm{A} 1 \mathrm{a}+1.33$

$\times \mathrm{Coe}+2.4 \times \mathrm{Fib}-0.42 \times \mathrm{Hap}-0.59 \times \mathrm{IgA}$

$+1.22 \times$ Pre $+7.32 \times$ Tra +141

Equation for uterine carcinoma

$\mathrm{ESR}=1.26 \times \mathrm{Alb}-0.26 \times \mathrm{A} 1 \mathrm{~g}-1.44 \times \mathrm{A} 1 \mathrm{a}+0.001$ $\times \mathrm{Coe}+2.05 \times \mathrm{Fib}+0.32 \times \mathrm{Hap}+1.29 \times \mathrm{IgA}$ $-1.9 \times$ Pre $+1.96 \times$ Tra +128 
Tab. 3. Results of the analysis of erythrocyte sedimentation rate and plasma/serum profiles of 91 patients from part II of the study, and the equations using 10 or 9 plasma proteins shown in table 2 .

a) Multiple correlation coefficients $\left(R^{2}\right)$ of the four models. $R^{2}$ is the multiple correlation coefficient of each model. It is calculated as the sum of squaredeviations from the real erythrocyte sedimentation rate of the patients, and its predicted value calculated from the equation versus the sum of square differences between the erythrocyte sedimentation rate and the mean value of all erythrocyte sedimentation rate values from the group. It can be interpreted as the proportion of total variability of the erythrocyte sedimentation rate values within the group which is explained by the equation.

b) Probabilities in percent of correct or false differential a) diagnosis between the four models and diseases.

\begin{tabular}{lcccc}
\hline Patients & Models & & & \\
\cline { 2 - 4 } & Erysipela & $\begin{array}{l}\text { Malignant } \\
\text { melanoma }\end{array}$ & $\begin{array}{l}\text { Multiple } \\
\text { sclerosis }\end{array}$ & $\begin{array}{l}\text { Uterine } \\
\text { carcinoma }\end{array}$ \\
\hline Erysipela & 0.62 & -27.2 & -4.7 & -1.3 \\
$\begin{array}{l}\text { Malignant } \\
\text { melanoma }\end{array}$ & 0.24 & 0.99 & -1.15 & -0.06 \\
$\begin{array}{l}\text { Multiple } \\
\text { sclerosis }\end{array}$ & -1.05 & -13.7 & 0.98 & -22.9 \\
$\begin{array}{l}\text { Uterine } \\
\text { carcinoma }\end{array}$ & -35.3 & -52.18 & -3.43 & 0.61 \\
\hline
\end{tabular}

b)

\begin{tabular}{|c|c|c|c|c|}
\hline \multirow[t]{2}{*}{ Patients } & \multicolumn{4}{|l|}{ Models } \\
\hline & Erysipela & $\begin{array}{l}\text { Malignant } \\
\text { melanoma }\end{array}$ & $\begin{array}{l}\text { Multiple } \\
\text { sclerosis }\end{array}$ & $\begin{array}{l}\text { Uterine } \\
\text { carcinoma }\end{array}$ \\
\hline Erysipela & $72.5 \%$ & $2.5 \%$ & $10 \%$ & $15 \%$ \\
\hline $\begin{array}{l}\text { Malignant } \\
\text { melanoma }\end{array}$ & $7 \%$ & $86 \%$ & 0 & $7 \%$ \\
\hline $\begin{array}{l}\text { Multiple } \\
\text { sclerosis }\end{array}$ & $6.5 \%$ & 0 & $87 \%$ & $6.5 \%$ \\
\hline $\begin{array}{l}\text { Uterine } \\
\text { carcinoma }\end{array}$ & $13.5 \%$ & $4.5 \%$ & $18 \%$ & $64 \%$ \\
\hline
\end{tabular}

and this in fact proves to be correct (tab. 3). The table shows the probability of the correct or false diagnosis for the total of the 90 investigated patients: within the four blocks the correct diagnosis varies between 64 and $87 \%$.

Table 4 contains the two equations of part II of the study. Again there are distinct differences in the analogous coefficients of single plasma/serum protein concentrations. Accordingly the best fits for a differential diagnosis within these two blocks amount to 79 and $89 \%$ for multiple sclerosis and uterine carcinoma, respectively (tab. 5).
Tab. 4. Equations obtained in part II of the study. The coefficients are calculated from the plasma concentrations of 12 selected proteins.

For abbreviations cf. tab. 2

Equation for multiple sclerosis

$\mathrm{ESR}=-5.43 \times \mathrm{Alb}+3.67 \times \mathrm{A} 1 \mathrm{a}+6.72 \times \mathrm{A} 2 \mathrm{~m}-$ $2.76 \times \mathrm{Coe}+0.21 \times \mathrm{Crp}+2.5 \times \mathrm{Fib}+0.21 \times$

$\mathrm{Hap}+1.03 \times \mathrm{IgA}-1.44 \times \mathrm{IgG}+0.33 \times \mathrm{IgM}$ $+1.41 \times$ Pre $+2.25 \times$ Tra -570

Equation for uterine carcinoma

$\mathrm{ESR}=1.02 \times \mathrm{Alb}-2.06 \times \mathrm{A} 1 \mathrm{a}-0.20 \times \mathrm{A} 2 \mathrm{~m}+0.32$ $\times \mathrm{Coe}-0.03 \times \mathrm{Crp}+2.46 \times \mathrm{Fib}+0.32 \times \mathrm{Hap}$ $+1.13 \times \operatorname{IgA}-0.03 \times \mathrm{IgG}+0.31 \times \operatorname{IgM}-1.48$ $\times$ Pre $+2.37 \times$ Tra -190

Tab. 5: Results of the analysis of part II of the study (patients as in table 4):

a) Multiple correlation coefficients of the two models b) probabilities of right or false differential diagnosis.

a)

\begin{tabular}{lrl}
\hline Patients & \multicolumn{2}{l}{ Models } \\
\cline { 2 - 3 } & $\begin{array}{ll}\text { Multiple } \\
\text { sclerosis }\end{array}$ & $\begin{array}{l}\text { Urine } \\
\text { carcinoma }\end{array}$ \\
\hline Multiple sclerosis & 0.864 & -0.127 \\
Uterine carcinoma & -9.020 & 0.872 \\
\hline
\end{tabular}

b)

\begin{tabular}{lcl}
\hline Patients & \multicolumn{2}{l}{ Models } \\
\cline { 2 - 3 } & $\begin{array}{l}\text { Multiple } \\
\text { sclerosis }\end{array}$ & $\begin{array}{l}\text { Uterine } \\
\text { carcinoma }\end{array}$ \\
\hline $\begin{array}{l}\text { Multiple sclerosis } \\
\text { Uterine carcinoma }\end{array}$ & $79 \%$ & $21 \%$ \\
\hline
\end{tabular}

The first two parts were merely done to investigate the principle, i.e. the possibility of differential diagnosis by analysis of plasma protein concentrations and erythrocyte sedimentation rate. The result of the third part is especially promising. Here we compared multiple sclerosis patients and patients with different inflammatory diseases of the nervous system except multiple sclerosis. The two equations differ distinctly (tab. 6). The probability for correct diagnosis of the two disease groups was $93 \%$ (tab. 7).

\section{Discussion}

Our investigations are based on the following considerations. Former results (5) indicated the possible existence of functional and disease-specific connections between the erythrocyte sedimentation rate as a dependent variable and the concentrations of several plasma proteins as independent variables. 
Tab. 6. Equations of patients with multiple sclerosis and nonmultiple sclerosis inflammations of the nervous system in part III of the study. The equations consist of the concentrations of 10 selected plasma proteins.

For abbreviations cf. tab. 2

\section{Equation for multiple sclerosis}

$\mathrm{ESR}=-8.08 \times \mathrm{Alb}-0.15 \times \mathrm{A} 1 \mathrm{~g}+1.08 \times \mathrm{A} 1 \mathrm{a}-0.58$ $\times \mathrm{A} 11+3.11 \times \mathrm{A} 2 \mathrm{~m}+0.71 \times \mathrm{CC} 3+4.55 \times$ Coe $-0.31 \times \mathrm{Hap}+0.02 \times$ Pre $+2.48 \times$ Tra + 360

Equation for inflammations of the nervous system except multiple sclerosis

$\mathrm{ESR}=-11.91 \times \mathrm{Alb}+1.08 \times \mathrm{A} 1 \mathrm{~g}-0.04 \times \mathrm{A} 1 \mathrm{a}+$ $1.25 \times \mathrm{A} 11+2.41 \times \mathrm{A} 2 \mathrm{~m}+1.14 \times \mathrm{CC} 3+0.47$ $\times \mathrm{Coe}+0.09 \times \mathrm{Hap}-0.04 \times$ Pre $-0.55 \times$ Tra $+477$

Tab. 7. Results of the case analysis of part III of the stud (patients of table 6) with multiple sclerosis and with other kinds of inflammation of the nervous system:

a) multiple correlation coefficients of the two models:

b) probabilities of the right or false differential diagnosis.

a)

\begin{tabular}{lll}
\hline Patients & \multicolumn{2}{l}{ Models } \\
\cline { 2 - 3 } & $\begin{array}{l}\text { Multiple } \\
\text { sclerosis }\end{array}$ & $\begin{array}{l}\text { Inflammatory } \\
\text { diseases of the } \\
\text { nervous system }\end{array}$ \\
\hline $\begin{array}{l}\text { Multiple sclerosis } \\
\begin{array}{l}\text { Other inflammatory } \\
\text { diseases of the } \\
\text { nervous system }\end{array}\end{array}$ & 0.98 & 0.10 \\
\hline
\end{tabular}

b)

\begin{tabular}{lcc}
\hline Patients & \multicolumn{2}{l}{ Models } \\
\cline { 2 - 3 } & $\begin{array}{l}\text { Multiple } \\
\text { sclerosis }\end{array}$ & $\begin{array}{l}\text { Inflammatory } \\
\text { diseases of the } \\
\text { nervous system }\end{array}$ \\
\hline $\begin{array}{l}\text { Multiple sclerosis } \\
\begin{array}{l}\text { Inflammatory } \\
\text { diseases of the }\end{array}\end{array}$ & $93 \%$ & $7 \%$ \\
nervous system & $7 \%$ & $93 \%$ \\
\hline
\end{tabular}

These variables together would form a multidimensional space of parameters inside of which every patient would be characterized by a certain point. In the ideal case of measurements without experimental error, and with no parameters other than the measured ones influencing the erythrocyte sedimentation rate, it should be possible to derive equations of curves (in the simplest case straight lines) which contain all data points. And if the connections between the concentrations of plasma proteins and the erythrocyte sedimentation rate were sufficiently different for different diseases, one should be able to develop programs for differential diagnosis between diseases with elevated erythrocyte sedimentation rate: the greater the differences between the specific equations of two diseases the better the diagnostic efficiency.

In practice the data points will not lie on a curve, but rather be scattered around the expected curve, due to the experimental error of the measurements and other non-measured variables influencing the erythrocyte sedimentation rate.

The characteristic equation for a certain disease would be best derived by the method of least squares (multiple linear or non-linear) regression. For all data points of patients with a certain disease, the expected value of the distance from this curve is zero. However, data points of patients with other diseases would be expected to have distances more or less different from zero (depending on the differences of the two respective equations).

For proving such disease-specific equations one would have to measure the above mentioned variables on a sufficiently large group of patients with the disease, so that the addition of further patients would hardly change the equation derived from the data set. Furthermore, the division of a group of patients into two subgroups should yield two similar equations.

The procedure of handling of the disease-specific equations may be explained by an example. Suppose a malignant melanoma patient had a $1 \mathrm{~h}$-erythrocyte sedimentation rate of $50 \mathrm{~mm}$. The concentrations of his plasma/serum proteins are inserted into the malignant malinoma formula of table 2; if the calculated erythrocyte sedimentation rate is approximately $50 \mathrm{~mm}$, then the diagnosis is regarded as correct. Analogies can be made for the other cases in table 2, if one calculates the erythrocyte sedimentation rate from the adequate equation by inserting the respective protein concentration values.

In this study we tested two methods for measuring the protein concentrations and partly also different groups of proteins to find optimum conditions. However, none of these variations improved the results in any of the three parts.

The multiple sclerosis group values of part I and III are identical as they stem from the same patients. However, the corresponding two equations are partly different. The reason for this is that the proteins used in the equations of part I and III are only partly identical. These partial differences in the two equations show the importance of the choice of the measured proteins and the interdependence of the coefficients. The equation of the multiple sclerosis group 
of part II is based on the measurement of the protein concentrations by zone immunoelectrophoresis assay (ZIA), while those in part I and III are based on the Clarke-Freeman method. This may also account for its difference from to the multiple sclerosis-equations in part I and II.

From the result of part III two consequences follow:

a) even if only one organ system is involved, specific plasma/serum protein profiles may indicate distinct diseases and

b) different unspecific inflammatory diseases of the nervous system may be combined into one group in our analysis.

All previous investigations of the possible diseasespecific influence of the plasma/serum protein profile on the erythrocyte sedimentation rate have failed to produce positive results (see, e. g. 1. c. (13)). The reason for this is obviously that the correlations between protein concentrations and the erythrocyte sedimentation rate are weak. From our work, however, it can be concluded that the pattern of different plasma/ serum proteins to which the erythrocyte surface is exposed, i. e. the distribution of influences of the single plasmaproteins in dependence of the whole of the proteins seems to be more or less disease-specific and independent of the values of the erythrocyte sedimentation rate.

The results of the present study are challanging, but they do not definitely prove our hypothesis, because

a) the number of cases studied in some classes of disease was not quite sufficient, and

\section{References}

1. Fåhraeus, R. (1921) The suspension stability of the blood. Med. Scand. 55, 70-92.

2. Westergren, A. (1924) Die Senkungsreaktion. Ergeb. Inn Med. Kinderheilk. 26, 577-732.

3. Ruhenstroth-Bauer, G. (1966) Mechanismus und Bedeutung der beschleunigten Erythrozytensenkung. Klin. Wochenschr. 44, 533-539.

4. Scherer, R. \& Ruhenstroth-Bauer, G. (1972) Die Blutkörperchensenkung, gegenwärtiger Stand von Theorie und Praxis. Hippokrates 43, 61-75.

5. Scherer, R., Morarescu, A. \& Ruhenstroth-Bauer, G. (1975) Die spezifische Wirkung der Plasmaproteine bei der Blutkörperchensenkung. Klin. Wochenschr. 53, 265-273.

6. Albrecht, H. (1970) Zur unterschiedlichen Hemmbarkeit der Blutkörperchensenkung in vitro durch Prednisolon bei verschiedenen Krankheiten. Blut 21, 371-377.

7. Internat. Comm. for Standardization in Hematology: Reference Method for Erythrocyte Sedimentation Rate (ESR) Test of Human Blood (1971) Brit. J. Haematol. 24, 671 673. b) there were problems with the reproducibility of the protein quantification.

For the practical clinical application of sedimentation equations it is necessary to obtain sedimentation equations with general validity

a) by enlarging the number of measured plasma proteins and the number of patients of every disease group,

b) by using a plasma/serum concentration estimation method with high reproducibility and clinical practicability,

c) by selecting the best fitting proteins for the correlation calculations, and

d) by determining the equations of further diseases with elevated erythrocyte sedimentation rate. Obviously, with improvement, the results of calculations should be improved accordingly.

Beside this possibility of differential diagnosis, our findings demonstrate that the feed-back mechanisms of the concentrations of plasma proteins are interdependent, and that this interdependency is diseasespecific. This may help in understanding the defence reaction of diseases with an elevated erythrocyte sedimentation rate.

\section{Acknowledgement}

For the protein assays the skillful technical assistance of Mrs. $H$. Saranius and Frau B. Wolff are gratefully acknowledged.

8. Clarke, H. G. M. \& Freeman, T. (1968) Quantitative Immunoelectrophoresis of Human Serum Proteins. Clin. Sci. $35,403-412$.

9. Vesterberg, O. (1980) New Sensitive Method for Quantitative Determination of Proteins by Zone Immunoelectrophoresis. Z. Anal. Chem. 301, 134-135.

10. Vesterberg, O. (1982) Protein Quantification with Zone Immunoelectrophoresis Assay (ZIA) In: Elektrophorese Forum '82 (Radola, B. J., ed.) München Oktober 1982.

11. Rose, A. S., Ellison, C. N. \& Myer, L. W. (1976) Criteria for the Clinical Diagnosis of Multiple Sclerosis. Neurol. 26 (Suppl. II), 20-22.

12. Chatterjee, S. \& Price, B. (1977) Regression Analysis by Example. Wiley Series in Probability and Mathematical Statistics. New York Univ. New York.

13. Scherer, R. \& Ruhenstroth-Bauer, G. (1983) Immunologische Untersuchungen der quantitativen Plasmaproteinveränderungen beim Erysipel. Hautarzt 34 (Suppl. IV), $280-281$.

Prof. Dr. G. Ruhenstroth-Bauer

Max-Planck-Institut für Biochemie

W-8033 Martinsried bei München 